\title{
Family Business in Agriculture: Challenge and Strategy to Face Global Business
}

\author{
Nyayu Lathifah Tirdasari \\ School of Business \\ IPB University (Bogor Agricultural \\ University) \\ Bogor, Indonesia \\ nyayuindonesia@gmail.com
}

\author{
Dikky Indrawan \\ School of Business \\ IPB University (Bogor Agricultural \\ University) \\ Bogor, Indonesia \\ rdikky@gmail.com
}

\author{
Idqan Fahmi \\ School of Business \\ IPB University (Bogor Agricultural \\ University) \\ Bogor, Indonesia \\ ifahmi.mk@gmail.com
}

\begin{abstract}
Family business as the most business practice in the agricultural sector faces a challenge from global business via the Free Trade Agreement (FTA). The purpose of this paper is to provide business strategies that support the competitiveness of the family business in the global value chain. We reviewed related literature on family business and agriculture to describe the challenge and propose strategies that can bridge agricultural family business to become competitive. The study highlighted two challenges, namely labor usage, and capital usage. The amount of labor usage in Indonesia's family business was higher than the global business. However, the competitiveness by labor usage was determined by knowledge transfer and farmers' cooperation. Thus, the total value of capital usage in Indonesia's family business was lower than the global business. The capital usage was driven the competitiveness by social capital reinforcement, capital allocation, and capital availability. In this case, The Indonesian family business was found not able to take advantage of capital usage. The study proposed a strategy for the family business was to overcome the threat of labor usage by using its capital usage strength. These findings highlighted the importance of strengthening family business in agriculture sector based on each strength to overcome global trade challenge and take the opportunity from it. This paper may avail governments in drawing up policies for assisting the family business in the agriculture area to get global. It also contributes to the limited source of references literature regarding family business in agriculture in Indonesia.
\end{abstract}

Keywords - family business, agriculture, business strategy, global trade, global value chain

\section{INTRODUCTION}

Indonesia has been actively participated in the Free Trade Agreement (FTA) and paid close attention to agriculture trade as this sector is the second-largest contributor to economic growth. Indonesia's active involvement in FTA has shown no significant influence on Indonesia's agriculture trade growth. The agriculture sector performance received negative results and predicted run into pressure [1]. Price reduction at the farmer is higher than at the consumer, which leads to no incentive for farmers to produce and export. Other ASEAN members, especially Thailand, Malaysia, and Vietnam have increased competition by producing similar agriculture products and pressured Indonesia's product. Therefore, Indonesia becoming more concern about how agricultural businesses can survive in global business. Especially, a large number of agricultural businesses is known as an independent family business. Family business dominates the business running in Indonesia. This type of business broaden in assorted sectors and needs supports from many parties to face succession and to achieve sustainable. This is to guarantee the family business continuance can be achieved and avoids the production discontinuance. Thus, the family business in agriculture can be more competitive to produce agriculture products.

Differently, from other types of family business, family business in agriculture is more concerned with their business continuance. They value their business more than just a tool to earn a profit. The family business is perceived as a family existence and heritage to the future generation. Therefore, family business in agriculture is known for its ability to survive beyond multiple generations and over a century [2]. This fact is the main reason for the research investigation. Especially in Indonesia, studies that investigating family business in the agriculture sector are considered limited. By looking at the relation between family business in agriculture, we found literature focused on aging farmers in agriculture. Currently, with a decreasing number of agrarian societies, most farmers are over 45 years old because the young generation is reluctant to pursue a career in agriculture. Therefore, the succession issue in agriculture is often occurring since many predecessors failed to encourage their successors to be involved in their family business. One study that can be used as a reference is related to the family restaurant business in Indonesia with regards to their plan for succession [3]. The paper specifically focuses on the challenge and strategy of the family business to face global business via the FTA.

A thorough study of the challenge and strategy on family business within the agriculture sector in Indonesia has not been performed before. Therefore, the purpose of this paper is to provide the business strategies that support the competitiveness of the family business in agriculture in Indonesia with regards to the global value chain. First, the paper reviewed the related literature on the family business in agriculture. Second, the paper analyzed and identified the internal strengths and weaknesses, as well as the external opportunities and threats of the family business to propose strategies. The paper contributes specifically to the family business literature that focuses on the agriculture sector and business continuance. 


\section{MATERIALS AND METHODS}

The study used a qualitative methodology to examine complex relationships between the family business and the agriculture sector and their effort to face business competition globally. This methodology was used to provides information from the collected data that guides authors to develop new insights and offers new ways of understanding issues [4]. The insight described family business based on their current conditions related to global business challenges. The data were collected and selected from the available online literature. The selection criteria were based on the first and second research questions as follows: "What are the challenges faced by a family business in agriculture to be competitive in global business?" and "What are the global competitive strategies that can be applied by a family business in agriculture?".

The study consists of three steps to perform the analysis. First, literature related to the family business and agriculture were reviewed. The literature study was performed to examine the current conditions to identify the internal strengths and weaknesses, as well as the external opportunities and threats of the family business. This was done by several steps as follows: at first, the topics of family business were explored; continued by the search the topics based on family business in agriculture; we used the Strengths-Weaknesses-Opportunities-Threats (SWOT) analysis so we listed the key factors on strengths, weaknesses, opportunities, and threats; we terminated our research by information saturation. Second, to decide a proper global competitive strategy for a family business, we employed expert judgment to rate the selected strengths, weaknesses, opportunities and threats. Likert scale was used in the semi-structured questionnaires. Three experts were chosen to fill in the questionnaires. Finally, we analyzed the results to combine the challenge and the strategies that can supports family business in agricultural to become competitive.

The study employed expert judgment to rate the selected factors using likert scale in the semi-structured questionnaires. The rate were aimed to know how important the selected factors influence the business to be globally competitive. As well to know the time span of the selected factors can be implemented. Each rates was figured using IFE (Internal Factor Evaluation) and EFE (External Factor Evaluation) with the result that obtained the weighted score. This score showed the strategic position in IFE-EFE Matrix (Figure 1).

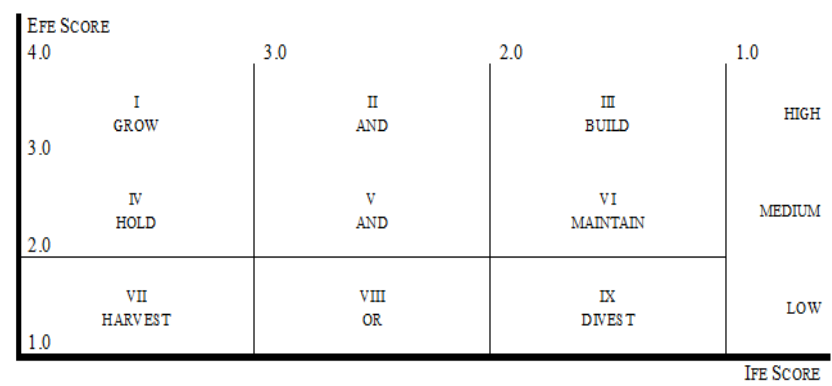

Fig. 1. IFE-EFE Matrix

\section{RESULTS}

The results showed determining factors of a family business in agriculture based on four categories of SWOT: strengths, weaknesses, opportunities, and threats from previous studies (Table I). We found 6 strengths, 5 weaknesses, 4 opportunities and 5 threats as determining factors for family business competitiveness in the agricultural sector.

TABLE I. DETERMINING FACTORS OF FAMILY BUSINESS COMPETITIVENESS IN AGRICULTURE

\begin{tabular}{|c|c|c|}
\hline Category & Factors & Studies \\
\hline Strengths & $\begin{array}{l}\text { - Local food and labor } \\
\text { providers } \\
\text { - Family contributions } \\
\text { both managerial and } \\
\text { operational } \\
\text { - Interaction between farm } \\
\text { and family } \\
\text { - Small need of labor } \\
\text { - Land as the main } \\
\text { component in household } \\
\text { wealth } \\
\text { - Lifestyle and beliefs } \\
\text { involvement }\end{array}$ & $\begin{array}{c}{[5]} \\
{[2],[5],[6]} \\
{[2],[5],[6]} \\
{[5]} \\
{[7]} \\
{[6]}\end{array}$ \\
\hline Weaknesses & $\begin{array}{l}\text { - Lack of equipment } \\
\text { - Existence of chatting } \\
\text { culture } \\
\text { - Influenced by family } \\
\text { events } \\
\text { - Succession issue } \\
\text { - Small buying power }\end{array}$ & $\begin{array}{c}5] \\
{[8]} \\
{[5]} \\
\\
{[3],[5]} \\
{[9]}\end{array}$ \\
\hline Opportunities & $\begin{array}{l}\text { - Most influential } \\
\text { contributor to economic } \\
\text { growth } \\
\text { - FTA } \\
\text { - Essential to local } \\
\text { community and local } \\
\text { social capital } \\
\text { - Fundamental role to rural } \\
\text { environment } \\
\text { - Government concerns of } \\
\text { food availability }\end{array}$ & $\begin{array}{c}{[1],[10],[12]} \\
{[1],[10],[12]} \\
{[5]} \\
{[6],[11]}\end{array}$ \\
\hline Threats & $\begin{array}{l}\text { - Similar products } \\
\text { produced by fellow } \\
\text { ASEAN countries } \\
\text { - A poor stigma around the } \\
\text { profession of farmers } \\
\text { - Inadequate infrastructure } \\
\text { and labor usage } \\
\text { - Lacks of solid regulation } \\
\text { - Extensive supply chain } \\
\text { and capital usage }\end{array}$ & $\begin{array}{c}1] \\
{[11]} \\
{[1],[11]} \\
{[1],[11]} \\
{[5],[1]}\end{array}$ \\
\hline
\end{tabular}

We highlighted the most important and the least important factor for the internal and external factors that determined the family business competitiveness in the agricultural sector. Among the internal factors, the most important factor that considered as a strength of family business was a land. This factor was the main component in family household wealth. The most important factor that considered as a weakness of family business was the succession. The least important factor in family business strength was the amount of labor needed. Hence the least important factor that considered as weakness was the presence of chatting culture.

In the external factor, the most important factor that allowed the family business in agriculture was the recognition of agriculture as a crucial contributor to 
TABLE II. WEIGHTED SCORE OF FAMILY BUSINESS FACTORS IN AGRICULTURE SECTOR COMPETITIVENESS

\begin{tabular}{|c|c|c|c|}
\hline FACTORS & Weight & Rating & Weighted Score \\
\hline \multicolumn{4}{|l|}{ Internal factor } \\
\hline \multicolumn{4}{|l|}{ Strengths: } \\
\hline Local food and labor providers & $10 \%$ & 3.0 & 0.3 \\
\hline Family contributions both managerial and operational & $10 \%$ & 3.0 & 0.3 \\
\hline Interaction between farm and family & $10 \%$ & 3.0 & 0.3 \\
\hline Small need of labor & $10 \%$ & 1.7 & 0.1 \\
\hline Land as the main component in household wealth & $10 \%$ & 3.7 & 0.4 \\
\hline Lifestyle and beliefs involvement & $10 \%$ & 2.7 & 0.2 \\
\hline \multicolumn{4}{|l|}{ Weaknesses: } \\
\hline Lack of equipment & $10 \%$ & 3.0 & 0.3 \\
\hline Existence of chatting culture & $0 \%$ & 1.3 & 0.1 \\
\hline Influenced by family events & $10 \%$ & 2.7 & 0.2 \\
\hline Succession issue & $10 \%$ & 3.7 & 0.4 \\
\hline Small buying power & $10 \%$ & 3.0 & 0.3 \\
\hline TOTAL WEIGHTED SCORE & \multicolumn{2}{|c|}{$100 \%$} & 3.0 \\
\hline \multicolumn{4}{|l|}{ External factor } \\
\hline \multicolumn{4}{|l|}{ Opportunities: } \\
\hline Most influential contributor to economic growth & $10 \%$ & 4.0 & 0.5 \\
\hline FTA & $10 \%$ & 3.7 & 0.4 \\
\hline Essential to local community and local social capital & $10 \%$ & 2.7 & 0.2 \\
\hline Fundamental role to rural environment & $10 \%$ & 2.7 & 0.2 \\
\hline Government concerns of food availability & $10 \%$ & 3.3 & 0.3 \\
\hline \multicolumn{4}{|l|}{ Threats: } \\
\hline Similar products produced by fellow ASEAN countries & $10 \%$ & 3.0 & 0.3 \\
\hline A poor stigma around the profession of farmers & $10 \%$ & 3.3 & 0.3 \\
\hline Inadequate infrastructure and labor usage & $10 \%$ & 3.7 & 0.4 \\
\hline Lacks of solid regulation & $10 \%$ & 3.0 & 0.3 \\
\hline Extensive supply chain and capita usage & $10 \%$ & 3.3 & 0.3 \\
\hline TOTAL WEIGHTED SCORE & \multicolumn{2}{|c|}{$100 \%$} & 3.3 \\
\hline
\end{tabular}

economic growth. The most important factor that considered a threat was inadequate infrastructure, labor, and regulation. Whereas, the least important factor of opportunities was the fact that agriculture essential contribution to the community and social capital. The least important threats were while a similar product from other ASEAN countries and the lack of regulation (Table II).

Based on the results, the IFE weighted score was 3.0 and the EFE weighted score was 3.3. The combination of a weighted score of internal and external factors showed a strategic position in quadrant 1 of the IFE-EFE Matrix. This quadrant indicated that the choice of strategy for the family business in agriculture was to grow and build.

\section{DISCUSSION}

In order to compete in global trade, the family business has to recognize its internal and external environment. We compared the family business situation with other businesses in agriculture. We found that family business in agriculture, in general, is the motor of economic growth compared to other types of business such as cooperatives or personal business. It shows that family business is a good foundation for the agriculture sector to enhance the business globally.

The family business Internal factors got a weighted score of 3.0, which means the family business in agriculture has strong internal capabilities to utilize its strengths and overcome the business environments. As the land considered as the most important strength, it shows that owning lands is fundamental for the family business in agriculture. As land holds a strategic position as part of the agriculture balance sheet as well the main asset in agriculture wealth. Land also holds a strategic place in decision making of succession. Therefore it has a strong relation to the most important weakness factor: succession. Most of the family business had an implicit succession plan. Many of them had an uncertain succession plain. Most of the family business is doing succession while the business is growing. While it has long term consequences. The succession gives consequences that will determine the bridge of business continuance to be a global player. Therefore, it is important to arrange courses of business strategy for the family business in agriculture that involved all family members.

The opportunities and threats which affected the strategy got a weighted score of 3.3, which means external environments are in favor to support family business in agriculture to grow strongly. As agriculture is a crucial contributor to Indonesia's economic growth, it gives a wide opportunity for the family business to grow. Economic growth will give many opportunities for family businesses to achieve more profit and expand their businesses. While inadequate infrastructure and labor as the most important threats could be handled by the family business strength. At the same time, the government gives support by providing a big portion of capital expenses to increase productivity and efficiency, especially infrastructure and labor development.

From the results, the study highlighted two challenges, namely labor usage, and capital usage. The amount of labor usage in Indonesia's family business was higher than the global business. However, the competitiveness by labor usage was determined by knowledge transfer and farmers' cooperation. Thus, the total value of capital usage in Indonesia's family business was lower than the global business. The capital usage was driven the competitiveness by social capital reinforcement, capital allocation, and capital availability. In this case, the Indonesian family business was found not able to take advantage of capital usage.

The proposed strategy was to grow and build a family business in agriculture to become a global player. It means that the family business has an opportunity to enhance its business globally. Not only develop the market but also their global value chain. In this case, many family businesses in 
Indonesia have succeeded to enhance their business as a conglomerate business. It could involve a new business venture in other countries as a support for the current business. For instance, many palm oil farm businesses have become more integrated and coordinated from upstream to downstream. These findings highlighted the importance of strengthening family business in agriculture sector based on each strength to overcome global trade challenge and take the opportunity from it.

\section{CONCLUSION}

The study proposed a strategy for the family business was to overcome the threat of infrastructure and labor usage by using its capital usage strength. The study has strengthening the premise that it is important to consider the capital usage or the land as main component of the family business in agriculture sector wealth [7]. These findings highlighted the importance of strengthening family business in agriculture sector based on each strength to overcome global trade challenge and take the opportunity from it. This paper may avail governments in drawing up policies for assisting the family business in the agriculture area to get global. It also contributes to the limited source of references literature regarding family business in agriculture in Indonesia. The study may not be generalized to other sectors of family business.

\section{REFERENCES}

[1] N. Nasrudin, B.M. Sinaga, and D. Walujadi, Dampak ASEAN-China Free Trade Agreement (ACFTA) terhadap Kinerja Perekonomian dan
Sektor Pertanian Indonesia. Buletin Ilmiah Litbang Perdagangan 9 (2015) $1-23$

[2] J. L. Glover, Capital usage in family farm businesses. Journal of Family Business Management 3 (2013) 136-162.

[3] N.L. Tirdasari, and W. Dhewanto, Family business succession in Indonesia: A study of hospitality industry. Procedia-Social and Behavioral Sciences 57 (2012) 69-74.

[4] K.G. Corley, and D.A. Gioia, Building theory about theory building: what constitutes a theoretical contribution? Academy of management review 36 (2011) 12-32.

[5] M. Winter, and M. Lobley, Is there a future for the small family farm? A report to The Prince's Countryside Fund. (2016).

[6] M. Calus, and G.V. Huylenbroeck, The persistence of family farming: A review of explanatory socio-economic and historical factors, University of Toronto Press, 2010.

[7] A.K. Mishra, H.S. El-Osta, and S. Shaik, Succession decisions in US family farm businesses. Journal of Agricultural and Resource Economics 35 (2010) 133-152.

[8] P. Cush, and Á. Macken-Walsh, The Potential for Joint Farming Ventures in Irish Agriculture: A Sociological Review. European Countryside 8 (2016) 33-48.

[9] A. Magnan, New avenues of farm corporatization in the prairie grains sector: farm family entrepreneurs and the case of One Earth Farms. Agriculture and Human Values 29 (2012) 161-175.

[10] U. Dianniar, The Impact of Free Trade Agreements on Indonesia's Agricultural Trade Flows: An Application of the Gravity Model Approach. Unpublished Master Thesis. The Hague, the Netherlands (2013).

[11] S. Kondo, Future Farmers Indonesia : Saving The Country's Agrarian Industry, PHOENIX COMMUNICATIONS, nowbali.co.id, 2018.

[12] B. Hutabarat, ASEAN-China Free Trade Area: its implication to agricultural trade and investment in Indonesia. Analisis Kebijakan Pertanian 9 (2011) 19-31. 